\title{
A retrospective study of canine cutaneous food allergy at a Veterinary Teaching Hospital from Jaboticabal, São Paulo, Brazil
}

\author{
Estudo retrospectivo da dermatite trofoalérgica canina em um \\ Hospital Veterinário de Jaboticabal, São Paulo, Brasil
}

\author{
Mariana Cristina Hoeppner Rondelli ${ }^{\mathrm{I}}$ Michele Cristina de Camargo Oliveira ${ }^{\mathrm{I}}$ \\ Flavio Lopes da SilvaII Reinaldo Juan Garrido Palacios Junior"II \\ Mayara Corrêa Peixoto ${ }^{\mathrm{I}}$ Aulus Cavalieri Carciofi ${ }^{\mathrm{I}}$ Mirela Tinucci-Costa $^{\mathrm{I}^{*}}$
}

ABSTRACT

Cutaneous food allergy is an adverse immunological response, triggered by antigenic dietary components that may escape the digestion process and are absorbed intact through the gastrointestinal mucosa. In Brazil, there are only a few reports on cutaneous food allergy and antigenicity of food components used in pet food production. Thus, the aim of this report was to assess and describe data from medical records of canine patients diagnosed with cutaneous food allergy at a Veterinary Teaching Hospital from Jaboticabal, SP, Brazil, in order to evaluate epidemiological and clinical aspects related to this skin problem. From 2007 to 2012, 29 dogs received the diagnosis of cutaneous food allergy after an eight-week hypoallergenic elimination trial. Among them, purebred dogs were more frequent, as well as females, and their mean age was 50.4 months old. Pruritus was reported in all cases, especially in interdigital areas. In order to establish the diagnosis, most patients received home-cooked elimination diet, based on potato and lamb in approximately $80 \%$ of the cases. Besides, it was highlighted the importance of the hypoallergenic elimination diet being rigorously followed by dogs' owners, aiming the adequate control of the clinical signs related to cutaneous food allergy.

Key words: dogs, food allergy, hypoallergenic diet.

RESUMO

A dermatite trofoalérgica é uma resposta imunológica adversa, desencadeada por componentes dietéticos antigênicos que escapam do processo de digestão e são absorvidos intactos pela mucosa gastrointestinal. No Brasil, há poucos relatos acerca da dermatite trofoalérgica e da antigenicidade dos componentes utilizados na produção de alimentos para animais. Assim, o objetivo deste trabalho foi avaliar e relatar dados de prontuários de pacientes caninos diagnosticados com dermatite trofoalérgica em um Hospital Veterinário de Jaboticabal, SP, Brasil, a fim de analisar os aspectos epidemiológicos e clínicos relacionados a este problema de pele. De 2007 a 2012, 29 cães receberam o diagnóstico de dermatite trofoalérgica após oito semanas de dieta de eliminação hipoalergênica. Dentre eles, destacam-se os cães de raça definida e as fêmeas como mais frequentes, com idade média de 50,4 meses. Prurido foi a queixa relatada em todos os casos, especialmente na região interdigital. Para fins diagnósticos, a maioria dos animais recebeu dieta caseira de eliminação, a base de batata e carneiro em aproximadamente $80 \%$ dos casos. Ademais, destacase a importância de que a dieta de eliminação hipoalergênica seja criteriosamente seguida pelo proprietário, a fim de controlar adequadamente os sinais clínicos da dermatite trofoalérgica.

Palavras-chave: cães, dermatite trofoalérgica, dieta hipoalergênica.

\section{INTRODUCTION}

Cutaneous food allergy, also known as food hypersensitivity, is an adverse immunological response, triggered by antigenic dietary components, as proteins and other peptides that may escape the digestion process and are absorbed intact through the gastrointestinal mucosa (NASCENTE et al., 2006).

It is believed that $15 \%$ of canine population has any type of allergy, context in which food allergy is the third in incidence, preceded by flea/tick allergy dermatitis and atopic dermatitis (CARLOTTI et al., 1990; SCOTT et al., 2001; IHRKE, 2009). In Brazil, there are only a few reports on allergic dermatitis in general. SOUZA et al. (2009) have reported food allergy represented $3.2 \%$ of non-tumorous skin diseases in Santa Maria-RS. Cutaneous food allergy

\footnotetext{
'Departamento de Clínica e Cirurgia Veterinária, Faculdade de Ciências Agrárias e Veterinárias (FCAV), Universidade Estadual Paulista (UNESP), 14884-900, Jaboticabal, SP, Brasil. E-mail: mirelatc@fcav.unesp.br. "Corresponding author.

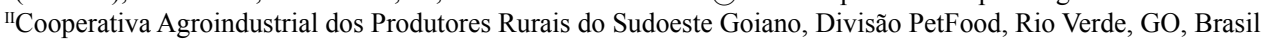

IIIMédico veterinário autônomo, São Paulo, SP, Brasil.
} 
was also reported by SALZO \& LARSSON (2009) when 20 from 117 suspected cases were confirmed by elimination dietary trial followed by provocative exposure, in a three-year study developed in São Paulo-SP, Brazil.

Any food has the potential to induce adverse reactions, but only a limited group of dietary ingredients was identified in veterinary medicine as responsible for those reactions (HENSEL, 2010), and they are wheat, beef, rice, lamb, soy, fish and dairy (WHITE, 1986; CARLOTTI et al., 1990; SALZO \& LARSSON, 2009). Most studies were developed in other countries and more information about the antigenicity of food components used in pet food production in Brazil is lacking. In this sense, a unique study developed in Brazil attempted to identify the allergenic dietary ingredients and has pointed beef as the most frequent component involved in food allergy, followed by rice and chicken (SALZO \& LARSSON, 2009).

The immediate hypersensitivity reaction mediated by IgE (type I) is the most common in food allergies (TAYLOR et al., 1987). The combination of an allergen with specific IgE fixated to tissue mast cells or to circulating basophiles provokes the releasing of histamine, serotonin and kinins, minutes after ingestion, or even hours after contact (ISHIZAKA \& ISHIZAKA, 1967; GASCHEN \& MERCHANT, 2011).

In dogs, one third to half of the cases of cutaneous food allergy involve patients with less than one year old (WHITE, 1986; CARLOTTI et al., 1990; HARVEY, 1993; ROSSER, 1993; WILLEMSE, 1995), although MEDLEAU \& HNILICA (2001) report that the onset may occur at any age. Furthermore, no sex predisposition has been identified for cutaneous food allergy (IHRKE, 2009). Many dog breeds were signaled with this skin disease, as Cocker Spaniel, Labrador retriever, Collie, Miniature Schnauzer, Shar Pei, West Highland White Terrier, Boxer, Dachshund, Dalmatian, Lhasa Apso, German Shepherd, and Golden retriever, for having a major risk to develop cutaneous food allergy when compared to other dog breeds (NESBITT \& ACKERMAN, 1998; SCOTT et al., 2001). It seems that purebred dogs have more risks in developing cutaneous food allergy than the crossbreed ones (IHRKE, 2009; SALZO \& LARSSON, 2009).

Clinically, cutaneous food allergy is one of the most pleomorphic skin diseases seen at the clinical practice. Non-seasonal pruritus leading to self-trauma is the clinical sign observed in most cases. When they occur, these skin lesions include erythema, papules, pustules, scaling, excoriation, erosion, epidermal collarettes, pododermatitis, seborrhea, alopecia, and pruritus, in general, severe and generalized, or localized (ROSSER, 1993; SCOTT et al., 2001; IHRKE, 2009). Face, ears, limbs and ventral region are the most affected areas. Secondary pyoderma and malasseziosis may contribute substantially to pruritus and to the lesion progress. Otitis externa is also usually observed in canine cutaneous food allergy (MEDLEAU \& HNILICA, 2001; IHRKE, 2009; GASCHEN \& MERCHANT, 2011). Most authors estimate less than $20 \%$ of animals with dermatological signs of food allergy present any gastrointestinal clinical signs (IHRKE, 2009; HENSEL, 2010; PROVERBIO et al., 2010).

Definitive diagnosis of cutaneous food allergy is given through eliminating diets that supposedly provoke the allergic reaction, followed by the provocative exposure (with the same causative diet) after clinical improvement (SCOTT et al., 2001; IHRKE, 2009; SALZO \& LARSSON, 2009; PROVERBIO et al., 2010). For this purpose, both home-made elimination diets and hypoallergenic pet food are available, although the use of home-cooked diets should be considered whenever a dog fails to respond to dietary restriction (RICCI et al., 2013). The main differential diagnosis for cutaneous food allergy are the other allergies; first, to fleas and ticks, followed by atopic dermatitis and contact dermatitis. Mites (scabies or demodicosis) must be ruled out initially as well as pyoderma and malasseziosis. An important aspect related to cutaneous food allergy is that poorly responds to corticotherapy, compared to other allergies (MEDLEAU \& HNILICA, 2001; PROVERBIO et al., 2010).

Treatment is based on the identification and withdrawing the food that may cause the sensitivity and periodic rechecks are required, and prognosis is considered good (MEDLEAU \& HNILICA, 2001; SCOTT et al., 2001).

Thus, the aim of this report was to assess and report data from medical records of canine patients diagnosed with cutaneous food allergy admitted at the Veterinary Teaching Hospital of FCAV/Unesp, Jaboticabal, SP, Brazil, from 2007 to 2012, in order to evaluate epidemiological and clinical aspects related to this skin problem in this São Paulo State region.

\section{MATERIALS AND METHODS}

The medical records of all dogs admitted to the clinical service of the Veterinary Teaching Hospital of FCAV/Unesp, Jaboticabal, SP, Brazil, 
from 2007 to 2012 that had the definitive diagnosis of cutaneous food allergy established by providing home-cooked or commercial hypoallergenic diet for at least 8 weeks were assessed. For so, a search at the information system of the Veterinary Teaching Hospital was performed, using the diagnosis of cutaneous food allergy (or food hypersensitivity) as an identification criterion of the medical records. Only cases with adequate monitoring and regular recheck that followed all steps for diagnosis and treatment were included.

In the first clinical assessment, when pruritus and other dermatological signs were noticed, the patient was examined using a Wood's Lamp, and trichogram, skin scraping, skin and ear cytologic analysis as well as otoscopy were performed, besides complete blood count and serum biochemistry. At this time, the prescription for the next 30 days included: (1) a strict spot-on tick and flea control every 21-28 days, added by environmental control, and oral nitenpyram $\left(1 \mathrm{mgkg}^{-1}\right.$ every 48 hours for three times) when flea infestation was suspected; (2) weekly bathing with antiseptic and moisturizing shampoo was recommended; (3) external otitis was also treated, according to the ear canal cytology; (4) secondary fungal or bacterial infections were also treated, accordingly; (5) antihistamine (cetirizine, hydroxyzine or clemastine) in association, in most cases, with prednisone $\left(0.5-1 \mathrm{mgkg}^{-1}\right.$ every 24 hours for 15-30 days) were prescribed in order to have pruritus controlled.

Thirty days after the first assessment, the patient was rechecked, and the clinical progression was reported by the owner. If pruritus remained, although the treatment suggested or the remission of the other clinical signs, then, cutaneous food allergy was considered as a differential diagnosis and the elimination dietary trial was indicated, as followed. A home-cooked elimination diet was initially suggested to the owner, and a source of carbohydrate (potato, sweet potato, cassava or rice) and a source of protein (lamb, rabbit, pork or fish) were suggested. The selected ingredients were those the patient had no previous contact. The owner would point the preference or, in case of declining to prepare homecooked food, the commercial hypoallergenic pet food was recommended (Hypoallergenic Canine ${ }^{\circledR}$ Royal Canin). The home-cooked food was prepared only cooked in water in the first month, and salt, soy oil, mineral compounds and vitamins were only added in the second month of elimination dietary trial.

From this moment on, tick and flea control and weekly bathing were continued, but oral and topic antipruritic drugs were discontinued. It was determined during the dietary trial period in question that the dogs did not receive any type of medication with flavoring or in capsules or softgel, snacks or any other food for human consumption, as well as tooth paste with any flavor. In case of poor response to the elimination dietary trial, the patient was put under treatment with imunossupressive agents, as prednisone or cyclosporine and the therapeutic diagnosis of atopic dermatitis was given.

In order to score the pruritus severity, the owner was asked to measure its intensity, using a scale from 0 (no pruritus) to 10 (extremely severe pruritus), according to the scale RYBNÍCEK et al. (2008) have validated. The clinician also assessed pruritus, although subjectively, according to the remission of clinical signs and pruritus progression reported by the owner. These assessments were performed and recorded on the medical records every recheck. The patients that presented an improvement of the clinical signs, especially on pruritus, in approximately $70 \%$ or more after the eight-week hypoallergenic dietary trial were included in the study, whereas it was ruled out those patients that had a poor response to this approach or that presented clinical evidence of any other allergic skin diseases (tick/flea allergy dermatitis, contact dermatitis, atopic dermatitis).

\section{RESULTS AND DISCUSSION}

During the study period, 1.352 dogs were admitted to the referral clinic of the Veterinary Teaching Hospital with a dermatological complaint. From those, $29(2.14 \%)$ were dogs with clinical history and dermatological signs compatible with cutaneous food allergy that presented a positive response after hypoallergenic dietary trial, as the dermatological signs were properly controlled. In a study also developed in Santa Maria, Rio Grande do Sul State, Brazil, SOUZA et al. (2009) reported a prevalence of $3.2 \%$ for cutaneous food allergy. Similar percentage was registered by WILHELM \& FAVROT (2005), who observed 1.7\%. However, CARLOTTI et al. (1990), CHESNEY (2002) and PROVERBIO et al. (2010) have found 5\%, 7.6\% and $12 \%$, respectively. Indeed, there is a great difference between the reported prevalence rates due to the fact that in some studies related to cutaneous food allergy in dogs, the study population or even the criteria used to evaluate the clinical improvement were not clearly described (CHESNEY, 2001).

Among the dogs included in this study, 28 $(96.5 \%)$ were purebred dogs and one $(3.5 \%)$ was a 
crossbreed dog. This was also described in a study of SALZO \& LARSSON (2009), when $70 \%$ of the dogs with cutaneous food allergy were purebred dogs. Among the dogs of this study, 21.4\% $(n=6)$ were Maltese, $17.8 \%(n=5)$ were Yorkshire terrier, $14.3 \%$ $(n=4)$ Poodle, 10.7\% $(n=3)$ Lhasa Apso and one dog of the following breeds: Dachshund, American pit bull terrier, English pointer, Pinscher, St. Bernard, Irish setter, Brazilian Terrier, Labrador retriever, Akita and Cocker spaniel, corresponding to $3.4 \%$ of the cases admitted. It was observed that Maltese dogs were the most affected dogs in this study, similarly observed by PROVERBIO et al. (2010) in Italy. From all dogs, $69 \%$ were female $(n=20)$ and $31 \%$ were male dogs but, in contrast to the data of this study, a Brazilian study performed in São Paulo, SP, reported more male dogs $(60 \%)$ diagnosed with cutaneous food allergy than females (SALZO \& LARSSON, 2009). Their age ranged from 10 to 108 months olds, with mean age of 50.4 months old. The age of the affected patients in this study agrees with what was reported by MEADLEAU \& HNILICA (2001). For these authors, cutaneous food allergy may occur at any age. Most authors consulted (WHITE, 1986; CARLOTTI et al., 1990; HARVEY, 1993; ROSSER, 1993 ) report that nearly $50 \%$ of the cutaneous food allergy cases have the clinical signs onset in the first year of life, which differs from this research. The most affected age groups were $41.4 \%(\mathrm{n}=12)$ from 36 to 72 months olds, $31 \%(\mathrm{n}=9)$ from 12 to 24 months olds, $20.7 \%(n=6)$ from 84 to 96 months olds, and $3.4 \%$ $(n=1)$ were 108 months old. Similar age distribution was reported by SALZO \& LARSSON (2009), with $35 \%$ of dogs from 48 to 72 months olds as the most affected with cutaneous food allergy.

The most observed clinical signs were pruritus (100\%), alopecia/hypotricosis in nine dogs $(31 \%)$, erythema in also nine dogs $(31 \%)$, scaling in six $(20.6 \%)$, pustules in five $(17.2 \%)$ and abdominal hyperkeratinization in three patients $(10.4 \%)$. Gastrointestinal signs were seen in two cases $(6.9 \%)$ and otitis externa was present in seven dogs $(24.2 \%)$. Generalized pruritus was present in five dogs (17.3\%), whereas localized pruritus in the other dogs. The most common regions for pruritus were: interdigital in nine $(31 \%)$, ears in seven $(24.2 \%)$, periocular in five $(17.3 \%)$, axillary and perioral in four $(13.8 \%)$ and perineal in two dogs $(6.9 \%)$. Indeed, pruritus is the clinical aspect that bothers the dogs' owners, motivating them to seek a veterinarian. The other clinical signs (alopecia, hypotrichosis, hair loss, erythema and scaling) were also reported by different authors (MEDLEAU \& HNILICA, 2001; IHRKE,
2009; SALZO \& LARSSON, 2009), although nonspecific and being probably present in other allergic processes (GASCHEN \& MERCHANT, 2011). The presence of pustules in dogs with this skin disease may be either localized or disseminated. At this moment, pyoderma is already present, probably secondary to pruritus, which may also worsen it, favoring the skin lesion progress (MEDLEAU \& HNILICA, 2001).

Hyperkeratinization, identified in three cases, might indicate chronicity of the allergic skin disease (IHRKE, 2009). Gastrointestinal signs were verified in two dogs that besides the dermatological signs, also presented diarrhea and feces with mucus, although rarely present in cutaneous food allergy (CARLOTTI et al., 1990; IHRKE, 2009; PROVERBIO et al., 2010). These dogs had the clinical history of having received several treatments for gastroenteritis with no clinical response, and have recovered after the hypoallergenic dietary trial.

Among the dogs, 7 (24.1\%) presented itchy ears and otitis, and these conditions are commonly observed in dogs with cutaneous food allergy (MEDLEAU \& HNILICA, 2001; SCOTT et al., 2001; SALZO \& LARSSON, 2009). Some dogs may have only otitis due to several allergic processes, with no other clinical signs (SCOTT, 2001; MEDLEAU \& HNILICA, 2001; GASCHEN \& MERCHANT, 2011).

Regarding the type of food the dogs used to receive when cutaneous food allergy was suspected, it could be observed: super premium pet food in $44.8 \%$ $(\mathrm{n}=13)$, premium pet food in $24.14 \%(\mathrm{n}=7)$, standard pet food in $24.14 \%(n=7)$ and home-cooked food in $6.9 \%(n=2)$ of the cases. Still, $27.6 \%(n=8)$ received any type of red meat (beef) or chicken besides the pet food or the home-cooked diet previously described, and $3.4 \%(n=1)$ received hypoallergenic commercial food with snacks. Besides, $65.5 \%$ from all patients $(\mathrm{n}=19)$ received any type of snacks, such as white bread $(41.37 \%, \mathrm{n}=12)$, fruits $(20.7 \%, \mathrm{n}=6)$, dog biscuits $(17.3 \%, \mathrm{n}=5)$, bones for dogs $(13.8 \%, \mathrm{n}=4)$, cookies and biscuits for human consumption $(10.4 \%$, $\mathrm{n}=3$ ), canned meat, ham and sausages for human consumption $(6.9 \%, \mathrm{n}=2)$ and vegetables $(3.4 \%$, $\mathrm{n}=1)$. All dogs had already received, at any moment, medications with flavoring or in capsules or softgel.

As described, the type of food the dogs received when cutaneous food allergy was suspected consisted mainly of commercial pet food and homecooked food, besides of snacks. Both commercial pet food and snacks had protein ingredients from animal and vegetable source in their composition (CARCIOFI et al., 2009), and these ingredients 
are pointed as a possible cause for cutaneous food allergy in dogs (KENNIS, 2006). Although clinicians incriminate the preservatives, coloring and other additives as reasons for the allergic process, studies that prove their role in the immune mediated reaction were not found.

In addition to the clinical diagnosis, histopathology was performed in only three cases $(10.4 \%)$. The other $89.7 \% \quad(n=26)$ were diagnosed clinically, using the elimination trial as unique treatment.

In order to confirm the cutaneous food allergy diagnosis, all patients received the elimination hypoallergenic diet for a period of, at least, eight weeks. From those patients, $89.7 \%(n=26)$ received home-cooked hypoallergenic diet, as followed: rice with lamb in one case $(3.4 \%)$, potato with pork in another $(3.4 \%)$, potato with lamb in 23 cases $(79.3 \%)$, and potato with chicken in one case (3.4\%). In this last situation, the initial prescription had been lamb as the protein source, although the dog's owner offered chicken instead. In $10.4 \%$ of the cases $(n=3)$, commercial hypoallergenic pet food was indicated (Hypoallergenic Canine ${ }^{\circledR}$ Royal Canin).

After a period of eight weeks of elimination trial, all dogs presented remission of the clinical signs, showing clinical improvement of $70 \%$ or more of the dermatological signs, especially on pruritus. The 26 dogs that received home-cooked hypoallergenic diet were initiated at commercial hypoallergenic pet food (Hypoallergenic Canine ${ }^{\circledR}$ Royal Canin) after the first eight weeks. From these dogs, 22 continued well, without any clinical signs, while 4 dogs presented pruritus during the diet changing from home-cooked to commercial, and it was necessary to return these dogs to home-cooked hypoallergenic diet, in order to have pruritus controlled. The dogs that received commercial hypoallergenic food (Hypoallergenic Canine ${ }^{\circledR}$ Royal Canin) since the beginning $(n=3)$ were kept on this diet, and presented themselves clinically stable.

Most of the cases admitted (89.7\%) received home-cooked elimination diet for the diagnosis of cutaneous food allergy. It is recommended for this purpose because it is possible to adequate the patient to the new diet, based on the alimentary history avoiding, thus, food previously given at any moment of the patient's life (SCOTT et al., 2001; SALZO \& LARSSON, 2009). The use of commercial hypoallergenic food with hydrolyzed proteins, on the other hand, has also been described to be efficient in diagnosing and treating cutaneous food allergy in dogs (BIOURGE et al., 2004; OLIVRY \& BIZIKOVA, 2010). In the present report, 10.4\% $(n=3)$ of all dogs received elimination commercial diet since the first clinical evaluation and had showed clinical improvement. The transition period from home-cooked elimination diet to commercial hypoallergenic food aimed to make it more practical for the owner and safer to the patients in giving food with adequate nutrient concentrations, once many hypoallergenic home-cooked foods might be nutritionally misbalanced, and lead the patients to malnutrition(SALZO \& LARSSON, 2009). Although, in some cases, the clinical status had worsened with the dietary transition, this may have happened due to simultaneous offering of other foods, or to the lack of rigorously following the clinical prescription, as well as the eventual administration of medicine with flavoring or in capsules or softgel (GASCHEN \& MERCHANT, 2011) or, still, by a sensitivity reaction against any undeclared commercial pet food component (RICCI et al., 2013). RICCI et al. (2013) have reported that failure to respond to commercial limited antigen diets might happen for many reasons and therefore, before ruling out food allergy, a novel protein home-made diet should be considered if the dog is unresponsive to a commercial regimen.

None of the patients were exposed to the diet they received previously the diagnosis, in order to test the antigenic tolerance, although recommended by different authors to confirm the diagnosis (SCOTT et al., 2001; IHRKE, 2009; PROVERBIO et al., 2010; SALZO \& LARSSON, 2009). SALZO \& LARSSON (2009) were more successful in their study involving dogs with cutaneous food allergy, once the provocative exposure was performed in $81.8 \%$ of the cases. In this study, although the provocative exposure was suggested in all cases, the owners declined, fearing the pruritus relapse.

\section{CONCLUSION}

In conclusion, it could be observed regarding the patients' profile that purebred dogs were more affected than crossbred ones and most patients were younger than 72 months old when the diagnosis was given. Localized pruritus was more present than the generalized form. Most dogs received commercial pet food when cutaneous food allergy was suspected and, interestingly, almost three thirds received snacks. Elimination trials with home-cooked or commercial hypoallergenic food are both useful in diagnosis and treatment monitoring, improving the clinical signs. Importantly, hypoallergenic diet prescription should be rigorously followed by owners, without introducing not recommended foods. Finally, it can be concluded that more studies are necessary to determine prevalence, 
epidemiological and clinical aspects related to canine cutaneous food allergy in Brazil.

\section{BIOTHICS AND BIOSSECURITY COMMITTEE APPROVAL}

This study was conducted according to the local animal well-fare committee regulations (Comissão de Ética no Uso de Animais-CEUA) (protocol n. 026452/13).

\section{REFERENCES}

BIOURGE, V.C. et al. Diagnosis of adverse reactions to food in dogs: efficacy of a soy-isolate hydrolysate-based diet. In: WALTHAM INTERNATIONAL SCIENCE SYMPOSIUM: NATURE, NURTURE, AND THE CASE FOR NUTRITION, 2004, Bangkok, Thailand. Journal of Nutrition, v.134, p.2062S-2064S, 2004.

CARCIOFI, A.C. et al. Qualidade e digestibilidade de alimentos comerciais de diferentes segmentos de mercado para cães adultos. Revista Brasileira de Saúde e Produção Animal, v.10, n.2, p.489-500, 2009. Available from: <http://revistas.ufba.br/index. php/rbspa/article/view/1713/835>. Accessed: Mar. 05, 2012.

CARLOTTI, D.N. et al. Food allergy in dogs and cats. A review and report of 43 cases. Veterinary Dermatology, v.1, p.5562, 1990. Available from: <http://onlinelibrary.wiley.com/ doi/10.1111/j.1365-3164.1990.tb00080.x/pdf>. Accessed: May 04, 2013. doi: 10.1111/j.1365-3164.1990.tb00080.x.

CHESNEY, C.J. Systematic review of evidence for the prevalence of food sensitivity in dogs. Veterinary Record, v.148, p.445448, 2001. Available from: <http://veterinaryrecord.bmj.com/ content/148/14/445.full.pdf +html?sid=16a5f023-e9e3-4fla-a7ed26f48015f3ef>. Accessed: Jun. 10, 2013. doi: 10.1136/vr.148.14.445.

CHESNEY, C.J. Food sensitivity in the dog: a quantitative study. Journal of Small Animal Practice, v.43, p.203207, 2002. Available from: <http://onlinelibrary.wiley.com/ doi/10.1111/j.1748-5827.2002.tb00058.x/pdf>. Accessed: May 04, 2013. doi: $10.1111 / \mathrm{j} .1748-5827.2002$.tb00058.x.

GASCHEN, F.P.; MERCHANT, S.R. Adverse food reactions in dogs and cats. Veterinary Clinics of North America: Small Animal Practice, v.41, p.361-379, 2011. Available from: $<$ http:// www.sciencedirect.com/science/article/pii/S0195561611000246>. Accessed: Jun. 20, 2013. doi: 10.1016/j.cvsm.2011.02.005.

HARVEY, R.G. Food allergy and dietary intolerance in dogs: a report of 25 cases. Journal of Small Animal Practice, v.33, p.175-179, 1993. Available from: <http://onlinelibrary.wiley.com/ doi/10.1111/j.1748-5827.1993.tb02647.x/epdf $>$. Accessed: May 06, 2012. doi: 10.1111/j.1748-5827.1993.tb02647.x.

HENSEL, P. Nutrition and skin diseases in veterinary medicine. Clinics in Dermatology, v.28, p.686-693, 2010. Available from: <http:// www.sciencedirect.com/science/article/pii/S0738081X10000556>. Accessed: Nov. 10, 2013. doi: 10.1016/j.clindermatol.2010.03.031.

IHRKE, P.J. Doenças perivasculares da derme. In: GROSS, T.L. et al. Doenças da pele do cão e do gato. 2.ed. São Paulo: Roca, 2009. Cap.10, p.194-230.
ISHIZAKA, K.;ISHIZAKA, T. Identification of Gamma E-antibodies as a carrier of reaginic activity. Journal of Immunology, v.99, p.1187-1198, 1967. Available from: <http://www.jimmunol.org/ content/99/6/1187.long>. Accessed: Sept. 15, 2012.

KENNIS, R.A. Food allergies: update of pathogenesis, diagnosis and management. Veterinary Clinics of North America: Small Animal Practice, v.36, p.175-184, 2006. Available from: <http:// dx.doi.org/10.1016/j.cvsm.2005.09.012>. Accessed: Jan. 26, 2013. doi:10.1016/j.cvsm.2005.09.012.

MEDLEAU, L.; HNILICA, K.A. Hypersensitivity disorders.In: MEDLEAU, L.; HNILICA, K.A. Small animal dermatology. 2.ed. St. Loius: Elsevier, 2001. Cap.7, p.159-188.

NASCENTE, P.S. et al. Hipersensibilidade alimentar em cães e gatos. Revista Clínica Veterinária, n.64, p.60-66, 2006. Available from: <http:/www.revistaclinicaveterinaria.com.br/v1/ edicao/2006/setembro-outubro.html $>$. Accessed: Oct. 12, 2012.

NESBITT, G.H.; ACKERMAN, L.J. Canine \& feline dermatology: diagnosis and treatment. New Jersey: Veterinary Learning Systems, 1998. 498p.

OLIVRY, T.; BIZIKOVA, P. A systematic review of the evidence of reduced allergenicity and clinical benefit of food hydrolysates in dogs with cutaneous adverse food reactions. Veterinary Dermatology, v.21, p.32-41, 2010. Available from: <http://onlinelibrary.wiley. com/doi/10.1111/j.1365-3164.2009.00761.x/epdf >. Accessed: Oct. 14, 2013. doi: 10.1111/j.1365-3164.2009.00761.x.

PROVERBIO, D. et al. Prevalence of adverse food reactions in 130 dogs in Italy with dermatological signs: a retrospective study. Journal of Small Animal Practice, v.51, p.370-374, 2010. Available from: <http://onlinelibrary.wiley.com/doi/10.1111/ j.1748-5827.2010.00951.x/epdf>. Accessed: Nov. 14, 2013. doi: 10.1111/j.1748-5827.2010.00951.x.

RICCI, R. et al. Identification of undeclared sources of animal origin in canine dry foods used in dietary elimination trials. Journal of Animal Physiology and Animal Nutrition, v.97, p.32-38, 2013. Available from: $<$ http://onlinelibrary.wiley.com/doi/10.1111/ jpn.12045/epdf>. Accessed: Oct. 18, 2014. doi: 10.1111/jpn. 12045.

ROSSER, E.J. Diagnosis of food allergy in dogs. Journal of American Veterinary Medical Association, v.203, p.259262, 1993. Available from: <http://www.ncbi.nlm.nih.gov/ pubmed/8407485>. Accessed: Dec. 17, 2012.

RYBNÍCEK, J. Further validation of a pruritus severity scale for use in dogs. Veterinary Dermatology, v.20, p.115-122, 2008. Available from: <http://onlinelibrary.wiley.com/doi/10.1111/ j.1365-3164.2008.00728.x/full>. Accessed: Jan. 06, 2015. doi: 10.1111/j.1365-3164.2008.00728.x.

SALZO, P.S.; LARSSON, C.E. Food hypersensitivity in dogs. Arquivo Brasileiro de Medicina Veterinária e Zootecnia, v.61, n.3, p.598-605, 2009. Available from: <http://www.scielo.br/pdf/ abmvz/v61n3/12.pdf>. Accessed: Nov. 18, 2012.

SCOTT, D.W. et al. Muller \& Kirk's small animal dermatology. 6.ed. Philadelphia: Saunders, 2001. 1528p.

SOUZA, M.T. et al. Prevalence of non-tumorous canine dermatopathies in dogs from the municipality of Santa Maria, Rio Grande do Sul, Brazil (2005-2008). Pesquisa Brasileira 
Veterinária, v.29, p.157-162, 2009. Available from: <http://dx.doi. org/10.1590/S0100-736X2009000200013>. Accessed: Jun. 14, 2012. doi: 10.1590/S0100-736X2009000200013.

TAYLOR, S.L. et. al. Chemistry of food allergens. In: CHANDRA, R.K. Food allergy. St Johns: Nutrition Research Education Foundation, 1987. Cap.02, p.21-25.

WHITE, S.D. Food hypersensitivity in 30 dogs. Journal of American Veterinary Medical Association, v.188, p.693-
698, 1986. Available from: <http://www.ncbi.nlm.nih.gov/ pubmed/3700223>. Accessed: Nov. 21, 2012.

WILHELM, S.; FAVROT, C. Food hypersensibility dermatitis in the dog: diagnostic possibilities. Schweizer Archivfür Tierheilkunde, v.147, p.165-171, 2005. Available from: <http://www.ncbi.nlm.nih. gov/pubmed/15861923>. Accessed: Nov. 21, 2012.

WILLEMSE, T. Dermatologia clínica de cães e gatos. São Paulo: Manole, 1995. 143p. 